\title{
Synaptic Transmission between Pairs of Retinal Amacrine Cells in Culture
}

\author{
Evanna Gleason, Salvador Borges, and Martin Wilson \\ Division of Biological Sciences, Section of Zoology, University of California at Davis, Davis, California 95616
}

\begin{abstract}
We have examined synaptic transmission between isolated pairs of chick GABAergic amacrine cells, maintained in sparse culture and identified by their binding of an amacrine cellselective antibody. Using the perforated-patch method to whole-cell clamp both cells of a pair, postsynaptic currents were examined for step depolarizations of the "presynaptic" cell. Synaptic transmission, frequently reciprocal, was calcium dependent and reversibly blocked by bicuculline. Postsynaptic currents, excluding those due to ohmic electrical coupling, were elicited only for presynaptic voltage steps positive to about $-\mathbf{4 0} \mathrm{mV}$ and were always very noisy, suggesting that they were summed from relatively small numbers of quanta. Postsynaptic currents continued well after the termination of the 100 msec presynaptic voltage step when the step was to $-10 \mathrm{mV}$, or positive to this value. This result is interpreted to imply that presynaptic calcium concentration remains elevated after the membrane is returned to its holding potential.

When presynaptic voltages were kept low or else presynaptic voltage was uncontrolled, spontaneous quantal events mediated by GABA receptors could often be seen. Quanta rose quickly (less than $4 \mathrm{msec}$ ) and decayed with a mean time constant of $19.3 \mathrm{msec}$. The amplitude distributions of quantal currents were positively skewed, sometimes showing rare quanta of exceptionally large amplitude. Peak conductance per quantum was about $300 \mathrm{pS}$, corresponding to the simultaneous opening of only $17 \mathrm{GABA}_{\mathrm{A}}$ channels and corresponding to a net flux of only $32 \times 10^{3} \mathrm{Cl}^{-}$ions per millivolt of driving force. Estimates of the maximum sustained release rate at individual release sites suggest an upper bound of between 19 and 42 quanta per second.
\end{abstract}

[Key words: synapse, amacrine cell, retina, culture, GABA, quantal transmission]

Because the retina uses small slow signals, it might be supposed that its synapses differ markedly from those elsewhere in the nervous system. Scrutiny of this proposition is made difficult by numerous technical obstacles, not least of which is the difficulty of physiologically isolating a single synapse from among the wealth of connections found in the retina. To circumvent some of these problems we have cultured retinal neurons at low

\footnotetext{
Received July 14, 1992; revised Nov. 10, 1992; accepted Dec. 8, 1992.

We thank Colin Barnstable and Vance Lemmon for their generous gift of antibodies. We thank Andrew Ishida for a number of useful suggestions during the course of this work and Matt Frerking for carrying out some of the initial analysis in this study. This work was supported by EY 04112 to M.W.

Correspondence should be addressed to Martin Wilson at the above address.

Copyright (c) 1993 Society for Neuroscience $0270-6474 / 93 / 132359-12 \$ 05.00 / 0$
}

density (Gleason and Wilson, 1989) so that isolated pairs of cells might form synapses whose physiology might then be examined with relative ease. This approach has been successful elsewhere in the nervous system (e.g., Dietzel et al., 1986; O'Brien and Fischbach, 1986; Bekkers and Stevens, 1990; Malgaroli and Tsien, 1992) and has a precedent in the retina (MacLeish and Townes-Anderson, 1988). We describe here the results of experiments in which both cells of an isolated pair have been voltage clamped. We have concentrated on a recognizable population of cells previously shown to have amacrine-like properties (Huba and Hoffman, 1990, 1991) and confirmed here to be amacrine cells.

Amacrine cells form a diverse group (Masland, 1988) that in the retina make synaptic contact with other amacrine cells, bipolar cells, and ganglion cells (Dubin, 1970; Wong-Riley, 1974; Guiloff et al., 1988). The majority of amacrine cells probably use either glycine or GABA as a neurotransmitter although neuroactive peptides are commonly found in these cells as well (Brecha, 1983; Karten and Brecha, 1983; Li et al., 1985a,b). Huba and Hoffman (1991) have previously reported that cultured chick amacrine cells express receptors for both GABA and glycine. A general feature of amacrine cells is that, in common with other retinal neurons, they signal with slow, graded potentials, and though some are capable of producing one (Werblin and Dowling, 1969; Barnes and Wcrblin, 1986) or a few action potentials, with exceptions (Bloomfield, 1992; Wässle and Boos, 1992), they do not encode signals as trains of action potentials. It is presently unknown whether graded potentials or only action potentials are sufficient to elicit currents postsynaptic to amacrine cells but the experiments described here would suggest that presynaptic voltages greater than $-40 \mathrm{mV}$, whether sustained or transient, increase the probability of quantal release.

\section{Materials and Methods}

\section{Dissociation and culture methods}

The methods for dissociation and culture of embryonic chick retinal neurons have been previously described (Gleason et al., 1992). Briefly, $8 \mathrm{~d}$ chick embryo retinas were dissociated in $0.1 \%$ trypsin (Sigma, Si. Louis, MO) and seeded onto plastic tissue culture dishes (Falcon, Oxnard, CA) that had previously been coated with $0.1 \mathrm{mg}$ of poly-L-ornithine/ml (Sigma). Cells used for immunohistochemistry were plated onto poly-L-ornithine-coated glass-bottomed dishes (Bray, 1970).

Retinal cultures were maintained in a medium consisting of Dulbecco's modified Eagle's medium (Sigma) supplemented with 5\% fetal bovine serum (GIBCO, Grand Island, NY), $1000 \mathrm{U}$ of penicillin $/ \mathrm{ml}, 100$ $\mu \mathrm{g}$ of streptomycin/ml (Sigma), and $1 \mathrm{~mm}$ L-glutamine (Sigma). Cells were plated at a density of about $2.5 \times 10^{5}$ cells $/ 35 \mathrm{~mm}$ dish. At this density, it was possible to locate pairs of amacrine cells that were isolated from all other cells. The cultures were incubated at $37^{\circ} \mathrm{C}$ under a $5 \%$ $\mathrm{CO}_{2}$ atmosphere. 


\section{Immunocytochemistry}

Retinal cultures were fixed for $\mathbf{3 0} \mathrm{min}$ at room temperature in a solution containing 1\% paraformaldehyde in phosphate-buffered saline (PBS). After washing in PBS, cells were preincubated for $1 \mathrm{hr}$ in $5 \%$ normal goat serum (Sigma) in the dilution solution [PBS $+1 \%$ bovine serum albumin (Sigma) and $0.05 \%$ saponin]. This and all other incubations were carried out at room temperature. The primary antibodies, monoclonal antibody HPC-1 (a gift from Colin Barnstable, Yale University) and polyclonal antibody anti-GABA (Sigma) were incubated with the cells for $1 \mathrm{hr}$. A similar procedure was used with the monoclonal antibody 51-3g3 (a gift from Vance Lemmon, Case Western Reserve University), which we used to identify bipolar cells in culture and which was capable of recognizing them in retinal sections. The dishes were then rinsed in PBS and incubated for $1 \mathrm{hr}$ with the appropriate fluorescently labeled secondary antibody. After the final rinse, the cultures were coverslipped in a solution containing $70 \%$ glycerol, $28 \% \mathrm{PBS}$, and $2 \%$ (w/v) $N$-propyl gallate (Sigma) and examined on a Zeiss IM 35 inverted microscope outfitted with an epifluorescence unit.

\section{Electrophysiological recording}

Retinal cultures were prepared for electrophysiological recording by removing the normal culture medium and replacing it with the external recording solution (see below). The tissue culture dish was mounted on the stage of a Nikon inverted microscope and the cells were viewed with phase-contrast optics. A reference $\mathrm{Ag} / \mathrm{AgCl}$ pellet in $3 \mathrm{M} \mathrm{KCl}$ was connected to the culture dish via an agar bridge made up with $3 \mathrm{M} \mathrm{KCl}$. Amacrine cells were identified on the basis of their anatomy (see below).

Patch electrodes were pulled from thick-walled borosilicate glass (1.5 mm o.d., $0.86 \mathrm{~mm}$ i.d.; Sutter instruments, Novato, CA) on a FlamingBrown micropipette puller (Sutter Instruments). Tip resistance values were between 5 and $10 \mathrm{M} \Omega$ when measured in the bath. All recordings were made at room temperature $\left(22-24^{\circ} \mathrm{C}\right)$.

\section{Solutions}

Unless otherwise indicated, the following solution components were obtained from Sigma and are given in millimolar concentrations.

Internal solutions. Normal avian internal: $\mathrm{K}$ acetate, $140.0 ; \mathrm{KCl}, 10.0$; $\mathrm{MgCl}_{2}, 2.0 ; \mathrm{CaCl}_{2}, 0.1 ;$ HEPES, 10.0; EGTA, 1.1; and ATP, 1.0. Cesium internal: $\mathrm{Cs}$ acetate, $140.0 ; \mathrm{CsCl}, 10.0$; tetraethylammonium (TEA) acetate, 5.0; $\mathrm{MgCl}_{2}, 2.0 ; \mathrm{CaCl}_{2}, 0.1 ; \mathrm{HEPES}, 10.0$; EGTA, 1.1; and ATP, 1.0 (for whole-cell recordings only). All internal solutions were adjusted to $\mathrm{pH} 7.4$ with $\mathrm{KOH}$.

External solutions. Normal: $\mathrm{KCl}, 5.3 ; \mathrm{NaCl}, 136.9 ; \mathrm{CaCl}_{2}, 3.0 ; \mathrm{MgCl}_{2}$, 0.41; HEPES, 3.0; and glucose, 5.6. Normal TEA-tetrodotoxin (TTX): $\mathrm{KCl}, 5.3 ; \mathrm{NaCl}, 1$ 16.9; TEA Cl, 20.0; $\mathrm{CaCl}_{2}, 3.0 ; \mathrm{MgCl}_{2}, 0.41 ;$ HEPES, 3.0; glucose, 5.6; and TTX, $300 \mathrm{nM}$. Low-chloride TEA-TTX: KCl, 5.3; Na-isethionate, 116.9; TEA chloride, 20.0; $\mathrm{CaCl}_{2}, 3.0 ; \mathrm{MgCl}_{2}, 0.41$; HEPES, 3.0; glucose, 5.6; and TTX, $300 \mathrm{nM}$. All external solutions were adjusted to $\mathrm{pH} 7.4$ using $\mathrm{NaOH}$. External solution changes were achieved using gravity flow perfusion. Bicuculline (3-10 $\mu \mathrm{M})$, GABA $(3 \mu \mathrm{M})$, TTX $(300 \mathrm{nM})$, and $\mathrm{Co}^{2+}(3 \mathrm{~mm})$ were all bath applied. Diazepam $(3 \mu \mathrm{M})$ (Hoffmann LaRoche, Nutley, NJ) was pressure ejected through a pipette situated next to the cell.

\section{Whole-cell recordings}

Standard whole-cell recording methods (Hamill et al., 1981) were used to study voltage- and GABA-gated currents and to detect discrete events in single, isolated, amacrine cells. As described below, experiments involving cell pairs always employed the perforated-patch method for both cells. Amacrine cell capacitance values were measured from the patch clamp for each cell and ranged from 10 to $18 \mathrm{pF}$. Series resistance values were monitored repeatedly during each experiment and generally ranged from 15 to $30 \mathrm{M} \Omega$. The measured liquid junction potential between the normal internal and normal external solutions was $-7 \mathrm{mV}$. Current-voltage relations based on whole-cell recordings have been corrected for both series resistance and junction potential errors.

\section{Double perforated-patch recordings}

For detection of evoked synaptic currents, each of a pair of amacrine cells was voltage clamped using the perforated-patch technique (Horn and Marty, 1988). This configuration was used to prevent the dialysis of intracellular components that might be critical to synaptic transmis- sion. The pipette solution was prepared by mixing a stock solution of nystatin (Sigma) at $50 \mu \mathrm{g} / \mathrm{ml}$ in dimethyl sulfoxide (DMSO) 1:2 with a $25 \mathrm{mg} / \mathrm{ml}$ solution of Pluronic F-127 (Molecular Probes, Eugene, OR) in DMSO. This mixture was diluted then vortexed in the cesium internal solution to give a final nystatin concentration of $200 \mu \mathrm{g} / \mathrm{ml}$. Fresh internal solution was prepared from the nystatin stock about every $2 \mathrm{hr}$. Recording pipettes were filled with nystatin-containing internal solution and gigaohm seals were obtained by briefly hyperpolarizing $(>-100$ $\mathrm{mV}$ ) the patch prior to gaining electrical access to the cell. A slow capacity transient usually began to develop within seconds of seal formation. After the recording had stabilized, values for the cell capacitance were measured and these values fell within the same range as those determined for amacrine cells recorded in the whole-cell configuration.

During the first few minutes of an experiment, the series resistance value was usually too high to measure. Series resistance values were checked throughout each experiment, and within about $5 \mathrm{~min}$ the series resistance values commonly fell to about $70 \mathrm{M} \Omega$ but only rarely fell much below this. An examination of presynaptic currents (data not shown) revealed that $\mathrm{Ca}^{2+}$ currents dominate the presynaptic current voltage relations in the solutions used in these experiments. Typically, a maximum inward current of 100-200 pA occurred between 0 and $+10 \mathrm{mV}$, which we estimate would cause a steady-state voltage error of between 7 and $14 \mathrm{mV}$. Since presynaptic currents were not generally recorded, no correction for this error has been applied. Series resistance voltage errors in the postsynaptic cell were small because total current was always small (e.g., see Fig. 5A). As discussed by Korn et al. (1991), a junction potential is likely to exist between the pipette solution and the cell interior. No correction for this unknown offset has been applied.

\section{Analysis of quantal events}

Spontaneous postsynaptic currents were analog filtered using a four-pole Bessel filter (Axon Instruments) at a corner frequency of $500 \mathrm{~Hz}$ to 5 $\mathrm{kHz}$ and digitally sampled every $0.1-2 \mathrm{msec}$ before storage to disk. Peak amplitude histograms of quantal events were obtained from the digitized records using a computer program designed to find the maximum outward current relative to baseline current in a local region of the data identified by the user. Event amplitudes below a criterion value set by cell noise were ignored. This threshold for the reliable detection of quanta occurred between 2 and $5 \mathrm{pA}$, depending on the cell.

Single quantal events were analyzed for rise time to peak and their decay time constant. The $10-90 \%$ rise time was determined by first obtaining the peak and baseline currents. Linear interpolation between data points on the rising phase of quantal events was used to estimate the times of 10 and $90 \%$ peak current.

The decay of the quantal events was well fitted by an exponential function with a single time constant $\left(\tau_{D}\right)$. The time constant of decay was obtained by iterating through a range of $\tau_{D}$ values with the best fit to the measured currents established by eye.

\section{Results}

\section{Identification of amacrine cells in culture.}

Cultures of neurons derived from chick embryo retina contain several morphological cell types. One class of cell that we could readily identify was similar in appearance to the large multipolar neurons described by Huba and Hoffman (1990, 1991) and shown by them to possess some amacrine cell-like properties. In particular, that they accumulate tritiated GABA or muscimol and have electrophysiological properties similar to those recorded from amacrine cells in a retinal slice. Evidence presented below confirms the identification of these cells as amacrine cells.

Using cryostat sectioned adult chicken retina, we have examined the specificity of the antibody HPC-1 that in the rat retina recognizes a $35,000 \mathrm{kDa}$ protein that is a marker for amacrine cells (Barnstable et al., 1985) and has been used to identify rat amacrine cells in culture (Akagawa et al., 1990). In the chicken retina, the cell bodies and processes of amacrine cells were seen to bind HPC-1 strongly. In addition, however, some light staining of some cell bodies at the outer margin of the inner nuclear layer could be seen (data not shown). This pattern is, in fact, similar to that seen in rat (Barnstable et al., 

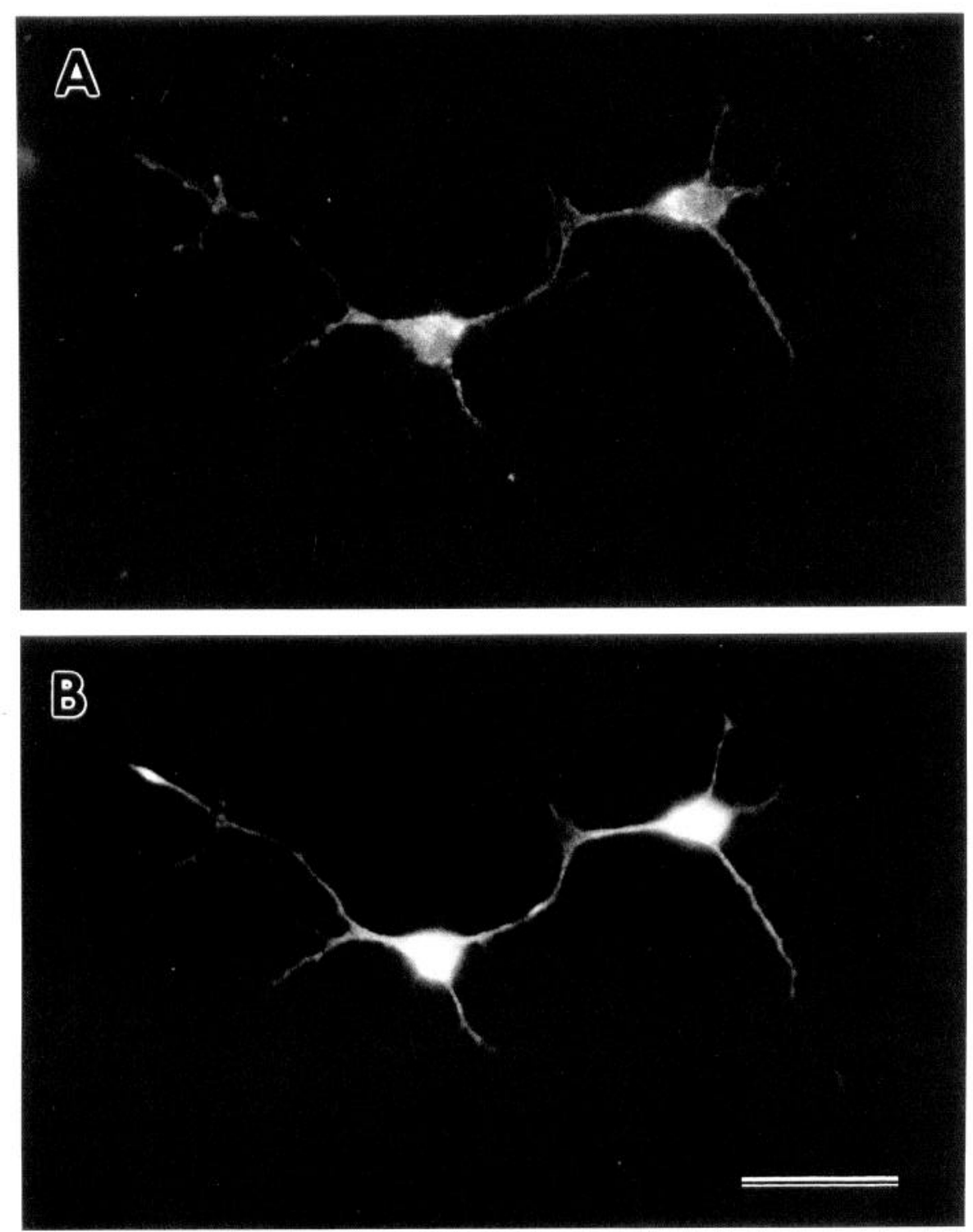

Figure 1. Large multipolar neurons bind both HPC-1 and anti-GABA antibodies. $A$, A field is shown that contains two large multipolar neurons after $5 \mathrm{~d}$ in culture. These cells have been labeled with the HPC-1 primary monoclonal antibody and a fluorescein isothiocyanate-conjugated secondary antibody. $B$, The same two cells shown in $A$ are also labeled with a primary polyclonal antibody raised against GABA and a rhodamine-conjugated secondary antibody. Both antibodies bind their respective antigens at the soma and at all of the processes of each neuron. Scale bar, $25 \mu \mathrm{m}$.
1985) and may imply that HPC-1 weakly recognizes some horizontal cells.

When used on retinal cultures, HPC-1 bound strongly to the large multipolar neurons (Fig. $1 A$ ) but not to cells that by independent criteria (Gleason et al., 1992) are known to be photoreceptors, or to cells that by their morphology and the binding of the antibody $51-3 g 3$ we classify as bipolar cells. Since we infer from its binding to retinal sections that HPC-1 may recognize horizontal cells, an ambiguity attends its use on our cultures. This ambiguity was removed by our finding (see below and Fig. 9) that all large multipolar neurons expressed the benzodiazepine receptor, which is found on amacrine cells but is known to be absent from horizontal cells of the chicken retina (Altstein et al., 1981; Brecha, 1983).

Large multipolar cells contain GABA, the likely transmitter of a substantial fraction of amacrine cells in the chicken retina (Brecha, 1983; Watt et al., 1988). Double labeling with HPC-1 and anti-GABA serum showed that, as illustrated in Figure 1, large multipolar neurons were almost invariably recognized by both antibodies. In a sample of 98 that were HPC-1 positive, an estimate of the percentage of cells scoring positive for GABA gave a value of $90 \%$. This value for dual labeling probably represents a low estimate because where the cells are dense, the apposition of an HPC-1-positive process along an HPC-1-negative cell body could give a false HPC-1-positive scoring.

Further evidence consistent with large multipolar cells being amacrine cells comes from their distinctive electrical properties. It is generally accepted that amacrine cells are the first cells in the visual pathway that normally produce action potentials. These action potentials are generated by inward sodium currents (Barnes and Werblin, 1986; Eliasof et al., 1987), but because of the relative voltage dependence of sodium and potassium gating, sustained, repetitive spiking is usually precluded. Using the current-clamp mode and whole-cell recording, current steps were applied to large multipolar cells in the presence of normal external solution and with a normal internal solution in the pipette. In these solutions, the average membrane potential was $-58 \pm$ $9 \mathrm{mV}$ (mean $\pm \mathrm{SD}, n=9$ ). Figure 2 shows typical voltage records in which outward current $(-100 \mathrm{pA})$ produced a voltage trajectory indicating passive charging of the membrane capacitance. Small inward current steps $(+100 \mathrm{pA})$ produced a small transient depolarization, and larger inward currents $(+700 \mathrm{pA})$ 


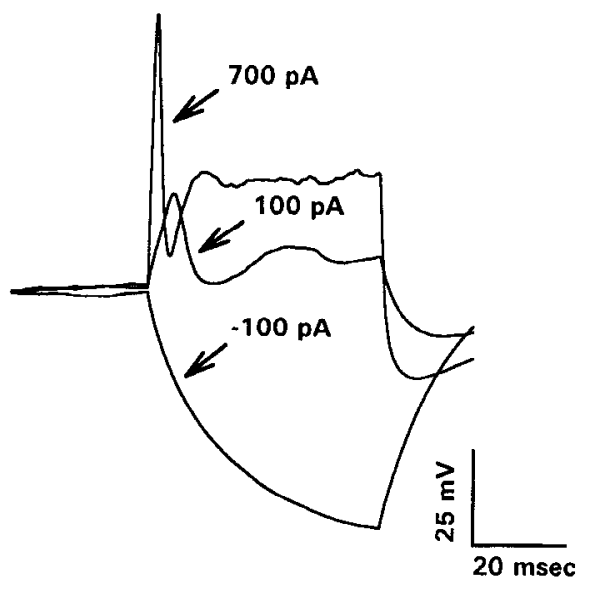

Figure 2. Large multipolar neurons produce single action potentials. Whole-cell current-clamp records in normal internal and external solutions are shown for a solitary cell with a resting potential of $-49 \mathrm{mV}$. The injection of negative current elicited a passive voltage response whereas current injection of $100 \mathrm{pA}$ produced a small voltage oscillation and $700 \mathrm{pA}$ produced a single action potential in this cell. Similar results were obtained in all of the large multipolar neurons examined $(n=9)$.

elicited a single spike. Repetitive spiking was never observed in any of the cells examined for any value of injected current.

To discover whether action potentials were sodium current dependent, we voltage clamped large multipolar cells and applied depolarizing steps from a negative holding voltage. As shown in Figure 3, a brief inward current could be elicited when stepping positive to about $-30 \mathrm{mV}$. Since this current was reversibly abolished by $300 \mathrm{nM}$ TTX, it is, as expected, a sodium current. An abrupt transition from no activated sodium current, to a fully activated current, apparent from the current-voltage relations for this cell (data not shown), suggested that the voltage clamp of these cells was less than perfect. Although with these large and fast currents clamp quality is poor, we show later that when these currents are suppressed, voltage and space clamp is adequate. While 17 of 21 cells examined behaved as described, 4 failed to show any inward current. Because these cells were only found in dishes previously superfused with TTX, we attribute this result to the presence of residual TTX that failed to flush out of the dish.

Taken together the results described above constitute a strong case that large multipolar cells are amacrine cells, and we will refer to them as such.

\section{Many amacrine cell pairs are electrically coupled}

To examine synaptic interactions between amacrine cells, we chose isolated pairs of cells that appeared to be in physical contact. Amacrine cell pairs were chosen according to three criteria. The first consideration was the cells' substrate. The presence of an underlying glial monolayer made it difficult to determine the extent of a cell's processes, so only cell pairs lying directly on the dish surface were selected for recording. The second requirement was that no processes from neighboring cells be contacting the cell pair. Finally, cell pairs were selected if their processes had multiple points of contact. Cell pairs with multiple contacts or a single large area of contact were much more likely to have functional synapses than pairs with scant physical contact. On average, about 10 such pairs could be found in each $35 \mathrm{~mm}$ culture dish seeded with $2.5 \times 10^{5}$ cells. To
A

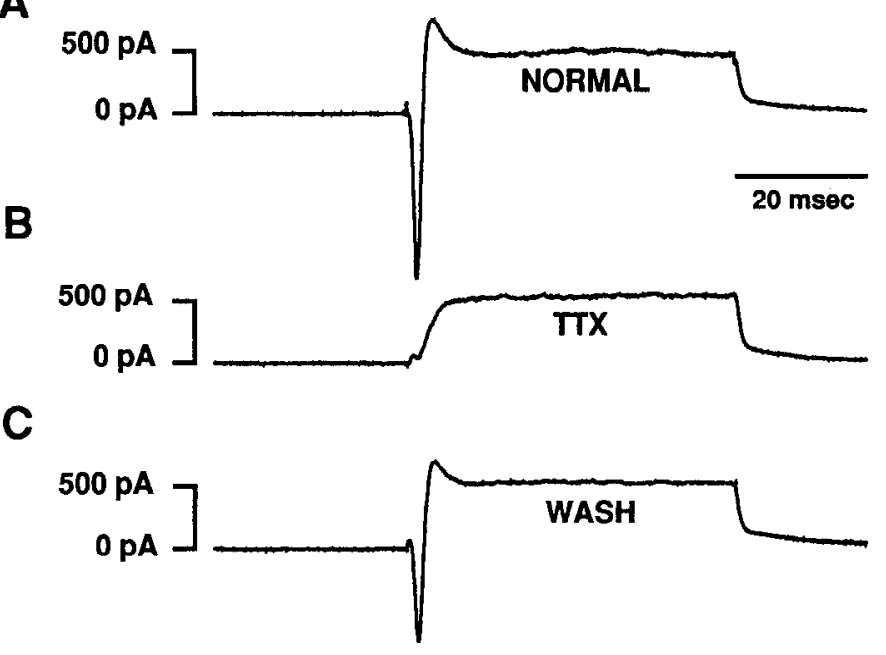

Figure 3. Large multipolar neurons have voltage-gated inward sodium currents. $A-C$ show whole-cell voltage-clamp recordings from a large multipolar neuron that were elicited from a holding potential of -50 $\mathrm{mV}$ with a $50 \mathrm{msec}$ voltage step to $-10 \mathrm{mV}$. $A$, In normal internal and external solutions, a quickly inactivating inward current was present. $B$, In the presence of $300 \mathrm{nM}$ TTX externally, the fast inward current was abolished and is therefore a sodium current. $C$, Removal of TTX from the bath gave partial recovery of the sodium current.

prevent the dialysis of cell contents associated with whole-cell patch clamping, we used the perforated-patch variant of this method (Horn and Marty, 1988), and to minimize space-clamp problems and reduce channel noise, $\mathrm{Cs}^{+}$replaced $\mathrm{K}^{+}$in the pipette solution and the external solution included $20 \mathrm{mM}$ TEA and $300 \mathrm{~nm}$ TTX.

In an initial survey of 103 amacrine cell pairs, $61 \%$ were found to be electrically coupled, with coupling conductances ranging from a few hundreds of picosiemens to a few nanosiemens. In all cases, electrical coupling was characterized by time-independent currents showing ohmic behavior but with no increase in noise (Fig. 4). We considered the possibility that even though the ohmic and reciprocal properties of this current are strongly suggestive of electrical coupling, an electrogenic release of transmitter might also be involved. Such a mechanism would predict that absolute membranc potential rather than the relative membrane potential of the two cells would determine the zero current voltage. In Figure $4 C$ the current-voltage relations for a cell pair are shown in which junctional current is expressed as a function of the membrane voltage of the "presynaptic" cell. As expected of simple electrical coupling, junctional current is zero exactly where junctional voltage is zero, whether the absolute membrane voltage of the pair is $-20 \mathrm{mV}$ or $-50 \mathrm{mV}$.

\section{Chemical synapses between pairs of amacrine cells}

Chemical synapses were detected in 55\% of the initial 103 amacrine cell pairs examined. Forty-nine percent of those connected pairs showed reciprocal synapses. In contrast to electrical junctions whose prevalence was independent of the age of a culture, chemical synapses were more frequently observed in old cultures. On day 5 in culture, $44 \%$ of cell pairs showed chemical synapses whereas on day $9,73 \%$ of cell pairs examined werc participating in chemical communication.

In all cell pairs examined that showed chemical transmission, 3 тм cobalt completely and reversibly abolished transmission 
A

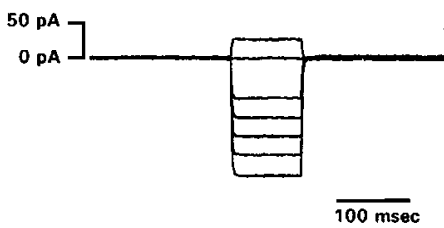

B

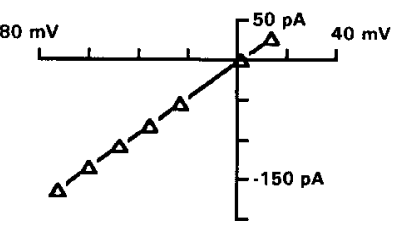

C

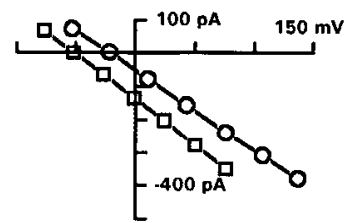

Figure 4. Many amacrine cell pairs are electrically coupled. $A-C$, Data were obtained by voltage clamping each of a pair of amacrine cells in the perforated-patch configuration with $\mathrm{Cs}^{+}$internal solution and normal TEA-TTX external solution. $A$, Currents recorded in the "postsynaptic" cell in response to a series of voltage steps applied "presynaptically" from a holding potential of $-70 \mathrm{mV}$ in pseudorandom order. The holding current has been subtracted from each trace. $B$, The current-voltage relationship for the data shown in $A$. Data are plotted as transjunctional current as a function of transjunctional voltage $\left(V_{j}=V_{\text {post }}-V_{\text {pre }}\right)$. $C$, For a different cell pair, junctional current is plotted as a function of the "presynaptic" voltage step (the difference in definitions of the voltage axis accounts for the change in sign of the conductances between $B$ and $C$ ). Holding potential for both cells was either $-20 \mathrm{mV}$ (circles) or $-50 \mathrm{mV}$ (squares). The conductance of the electrical synapse was approximately independent of holding potential and junctional current reversed when the transjunctional voltage was zero for both the -20 and $-50 \mathrm{mV}$ holding potential. Points have been corrected for series resistance errors.

elicited by $100 \mathrm{msec}$ voltage steps (Fig. $5 ; n=33$ ). This rules out, at least on the time scale of tens of milliseconds, the involvement of a nonvesicular calcium-independent release mechanism reported in some retinal neurons (Schwartz, 1982, 1987; Yazulla and Kleinschmidt, 1983) possibly including amacrine cells (O'Malley et al., 1992). Of the 103 cell pairs of various ages initially surveyed, $68 \%$ of the pairs that showed chemical synapses also showed electrical coupling. In these cells where electrical coupling could be clearly seen during hyperpolarizing steps, presynaptic depolarization produced a postsynaptic transient inward current followed by an outward current (Fig. 5A). As expected, in these cells, cobalt selectively abolished chemical transmission leaving a purely ohmic junctional current (Fig. 5B).

For simplicity, the experiments described here on chemical transmission have been carried out largely on pairs of cells in which no electrical coupling was seen, and because such pairs were commoner in older cultures we have concentrated on these. Except for the probability of encountering them, no differences between young and old synapses were observed and results have therefore been pooled. Since cells were put into culture on day 8 of development, a time prior to synapse formation in the intact developing chicken retina (Hughes and LaVelle, 1974), the increase in number of synapses with time probably reflects the normal developmental program for these cells rather than the repair of synapses broken by ccll dissociation, or the persistence of a small number of synapses that survived this procedure.

\section{Voltage dependence of transmitter release}

We began an examination of the chemical synapses between these cells in culture by looking at the voltage dependence of transmission, as well as the general form of the postsynaptic response. "Postsynaptic" cells were generally held at $0 \mathrm{mV}$ to ensure a large outward current while presynaptic voltage was held at $-70 \mathrm{mV}$ except during steps to more positive potentials. Since amacrine cells in the retina experience slow, graded signals, we have used $100 \mathrm{msec}$ steps to evoke transmitter release. Figure $6 A$ shows typical postsynaptic currents from 1 of 38 pairs of amacrine cells suitable for analysis. In all pairs examined, synaptic current first became detectable for presynaptic voltage steps to between -40 and $-30 \mathrm{mV}$. $\Lambda \mathrm{t}$ this voltage, postsynaptic currents were small and slow to reach a peak value. Peak current was generally reached sooner for bigger steps so that at $+10 \mathrm{mV}$ peak current generally occurred within $25 \mathrm{msec}$. Even for steps to $+10 \mathrm{mV}$, though, a synaptic delay of about 6 or $7 \mathrm{msec}$ was observed.

As is readily seen in Figure $6 A$, postsynaptic responses were graded with respect to presynaptic voltage and were very noisy, being apparently made up of discrete events or "quanta" whose frequency was a function of presynaptic voltage. Because of this, peak currents showed considerable variance, especially for relatively small voltage steps (e.g., -40 and $-30 \mathrm{mV}$ ), but as illustrated in Figure $6 B$ the trend was for peak currents to reach a maximum at about $-10 \mathrm{mV}$ and decline slowly for steps positive to this value. A considerable fraction of the variance between trials is eliminated by integrating postsynaptic current as is shown in Figure $6 C$. It is clear from this figure that transmission activates smoothly from about $-40 \mathrm{mV}$, consistent with the gradual activation of a $\mathrm{Ca}^{2+}$ current. In all pairs of cells, voltage steps positive to about $-10 \mathrm{mV}$ elicited currents

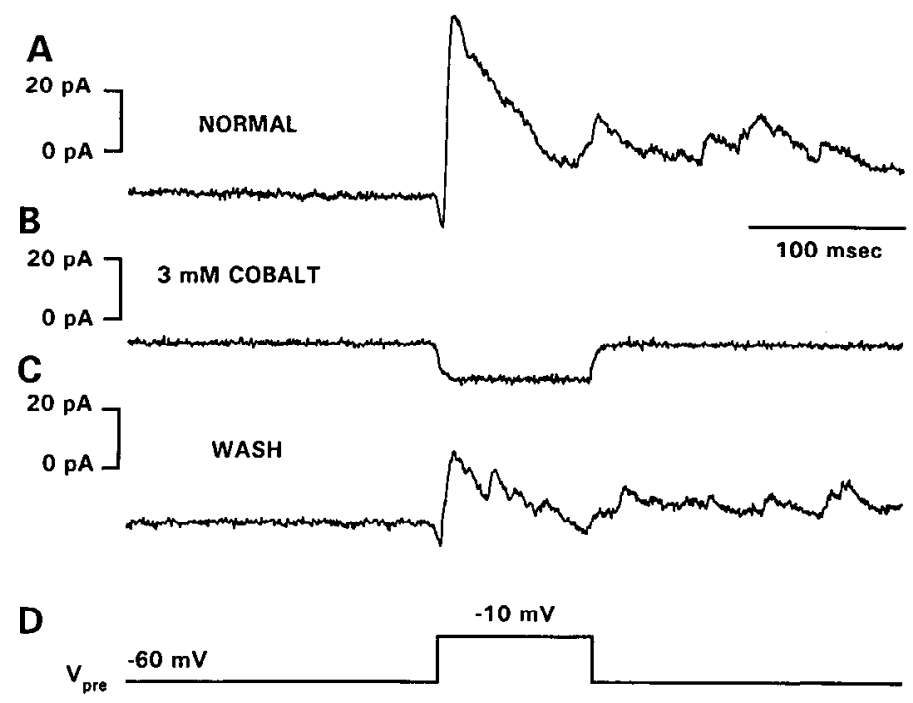

Figure 5. Chemical synaptic transmission is blocked by $3 \mathrm{~mm} \mathrm{Co} \mathrm{Co}^{2+}$ $A-C$, Perforated-patch voltage-clamp currents from a cell held at $0 \mathrm{mV}$ shown for the presynaptic voltage regime in $D$. $A$, In Cs pipette solution and in normal TEA-TTX external solution, the presynaptic voltage step elicited a biphasic postsynaptic current. $B$, Application of $3 \mathrm{mM} \mathrm{Co}^{2+}$ externally blocked the noisy outward component of the current but spared the inward current generated by electrical coupling between the two cells. $C$, after washing in normal TEA-TTX external, the noisy outward current component returned. 
Figure 6. Voltage dependence of transmitter release. $A$, Current records for the "postsynaptic" cell of an isolated pair, both of which were voltage clamped in the perforated-patch configuration. External solution contained TEA-TTX and the pipette solutions contained Cs. The "postsynaptic" cell was held at $0 \mathrm{mV}$ while the "presynaptic" cell was stepped from a holding voltage of $-70 \mathrm{mV}$ to command values, uncorrected for series resistance errors, indicated beside the current records. Voltage steps of $100 \mathrm{msec}$ were presented in pseudorandom order and elicited postsynaptic currents in which quantal noise is large. For the step to $-40 \mathrm{mV}$, a single quantum is elicited approximately $40 \mathrm{msec}$ after the beginning of the voltage step. Bigger voltage steps produce more postsynaptic current that outlasts the step duration. $B$, Peak current during steps is plotted against step voltage. Data have been averaged from six cells after normalizing their currents to a value of 1.0 at $+10 \mathrm{mV}$. Error bars indicate the very large SDs that are largely attributable to intertrial variance in the number of quanta released. Solid line shows an arbitrary function fitted by eye. $C$, Postsynaptic currents from four cells, shown with different symbols, have been integrated out to $200 \mathrm{msec}$ from the end of the voltage step. Charge for these four cells has been normalized to a value of 1.0 at $+10 \mathrm{mV}$. Variance is reduced by this procedure. The solid line is an arbitrary function fitted by eye.
A

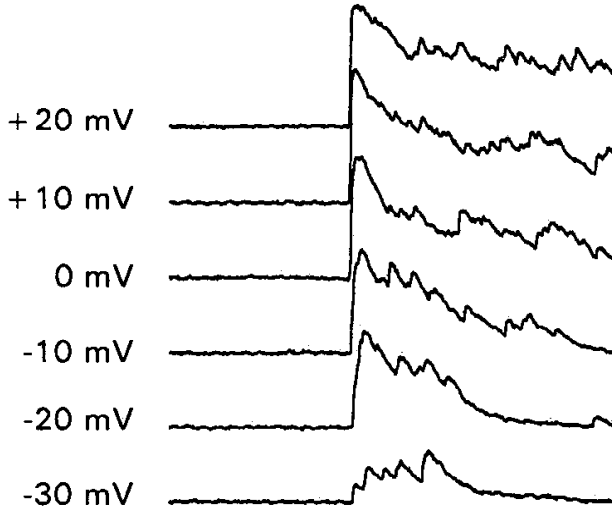

$-40 \mathrm{mV}$

$-50 \mathrm{mV}$

$-70 \mathrm{mV}$

$-80 \mathrm{mV}$
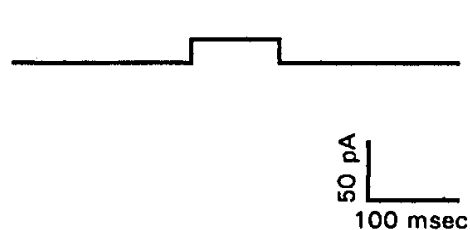

B
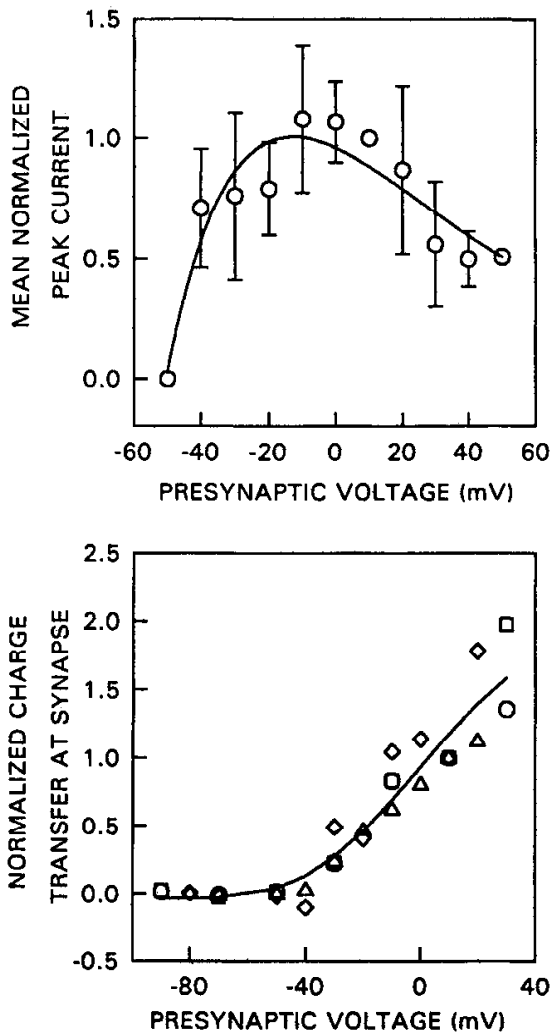

that outlasted the presynaptic voltage step, often for hundreds of milliseconds. As illustrated in Figure $6 \mathrm{~A}$ big voltage steps evoked a transient peak current that was followed by a decline to a sustained value over a time course of about $20-30 \mathrm{msec}$. A distinct peak was most clearly seen in those cells showing a relatively large postsynaptic current whereas in those having less than $50 \mathrm{pA}$, the noisiness of the current often precluded discrimination of a clear peak.

The nature of the variance in postsynaptic current between trials might be expected to reveal elements of the mechanism of these synapses, but we have not attempted its analysis since experiments on four cell pairs suggest that mean current is nonstationary. In these four cell pairs, steps of $100 \mathrm{msec}$ to +10 $\mathrm{mV}$ were repeated every $3.9 \mathrm{sec}$ in the presynaptic cell. For all four cells the trend over 10 trials was for smaller peak currents and charge per trial. A second process, one of augmentation of total charge for the first four or five trials, was indicated in two of the four cells. To minimize the spurious effects these processes might have on our examination of voltage dependence of transmitter release, two different voltage protocols were employed. In one, presynaptic voltages were chosen in a pseudorandom fashion; in the other protocol voltages were systematically incremented. The results reported here obtain for both protocols.

\section{Postsynaptic receptors are $G A B A_{A}$ receptors}

As shown in Figure 7, normal external chloride (149 mm) is associated with a reversal potential of about $-44 \mathrm{mV}$ for the postsynaptic cobalt-sensitive currents (mean $=-48.5 \mathrm{mV}, n=$ 4). This value is more positive than the $-59 \mathrm{mV}$ expected if chloride were the only ion carrying synaptic current. Since acetate is the predominant internal ion, a small permeability assigned to this ion would account for this discrepancy. If a value for $p_{\mathrm{Ac}}$ of 0.1 is assumed, consistent with the measurements of Bormann et al. (1987) for $\mathrm{GABA}_{\mathrm{A}}$ channels, then the predicted reversal potential is $-42 \mathrm{mV}$, closer to the observed value. In all six cells, lowering external chloride from $149 \mathrm{~mm}$ to $32 \mathrm{~mm}$ by substituting isethionate ions shifted the reversal potential substantially positive (mean reversal potential $=-17.7 \mathrm{mV}, n$ $=3$ ) (Fig. $7 B, C$ ). This result is consistent with chloride being a charge carrier for the postsynaptic current. The change in reversal potential, however, is less than expected (a mean positive shift of $-30.8 \mathrm{mV}$ as against an expected shift of $-39 \mathrm{mV}$ ), even when a finite $p_{\text {Ac }}$ of 0.1 is taken into account. A possible explanation for this is that low-chloride solutions fail to completely replace the high chloride when perfused into the culture dish. Experiments with dye flow through the dish revealed areas where replacement times were long.

A characteristic of GABA-gated chloride channels is their selective block by low doses of bicuculline. Bicuculline methiodide at 3 or $10 \mu \mathrm{M}$ was completely effective in 20 out of 20 cells at abolishing synaptic transmission between cell pairs in a partially reversible manner (Fig. 8). Bicuculline had no effect on current-voltage relations in the absence of synaptic stimulation. An important negative finding was that in the presence 


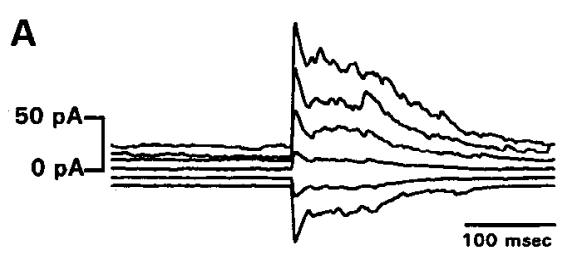

B

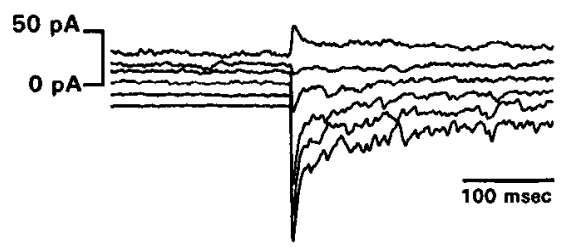

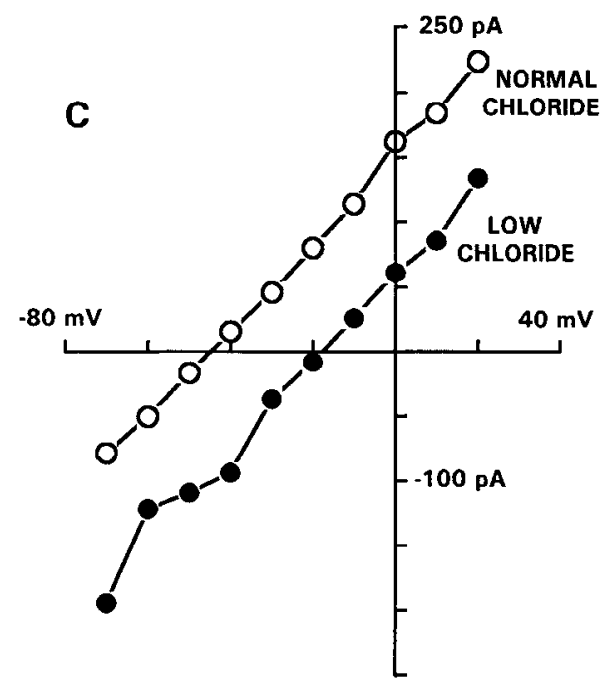

Figure 7. Reversal potential of the postsynaptic current depends on external chloride concentration. $A-B$, Current records obtained from a cell whose holding voltage was varied from about $-60 \mathrm{mV}$ to $-10 \mathrm{mV}$. Presynaptic voltage was held at $-50 \mathrm{mV}$ and stepped for $100 \mathrm{msec}$ to $+20 \mathrm{mV}$. Both cells of this pair were voltage clamped in the perforated-patch configuration with $\mathrm{Cs}$ in the pipette solutions. $A$, In normal TEA-TTX external solution (149 mM $\mathrm{Cl}^{-}$) the postsynaptic current reversed between -50 and $-40 \mathrm{mV}$. $B$, In low$\mathrm{Cl}^{-}$(32 mM) external solution, the reversal potential of the postsynaptic current was shifted positive to about -20 $\mathrm{mV}$. $C$, The leak-subtracted peak postsynaptic currents from the data in $A$ and $B$ (including data from additional postsynaptic holding potentials) plotted against postsynaptic holding voltage. These $I-V$ plots interpolate to give a reversal potential of $-44 \mathrm{mV}$ in normal external solution and of $-18 \mathrm{mV}$ in low-chloride external solution. of bicuculline a postsynaptic current having a different reversal potential was never observed, implying that $\mathrm{GABA}_{\mathrm{A}}$ receptors alone mediate synaptic transmission.

As determined by autoradiographic labeling of retinal sections, $\mathrm{GABA}_{\mathrm{A}}$ receptors of chicken amacrine cells, though not those from cells found in the outer plexiform layer, show benzodiazepine receptors (Altstein et al., 1981; Brecha, 1983). To establish the identity of our cells, we have used the benzodiazepine agonist diazepam, which has the effect of increasing the mean open time of $\mathrm{GABA}_{\mathrm{A}}$ receptors in the presence of GABA (Study and Barker, 1981). Macroscopically, the effect of diazepam binding can be detected as an increase in the amplitude of the GABA-gated current. As shown in Figurc 9, which con-

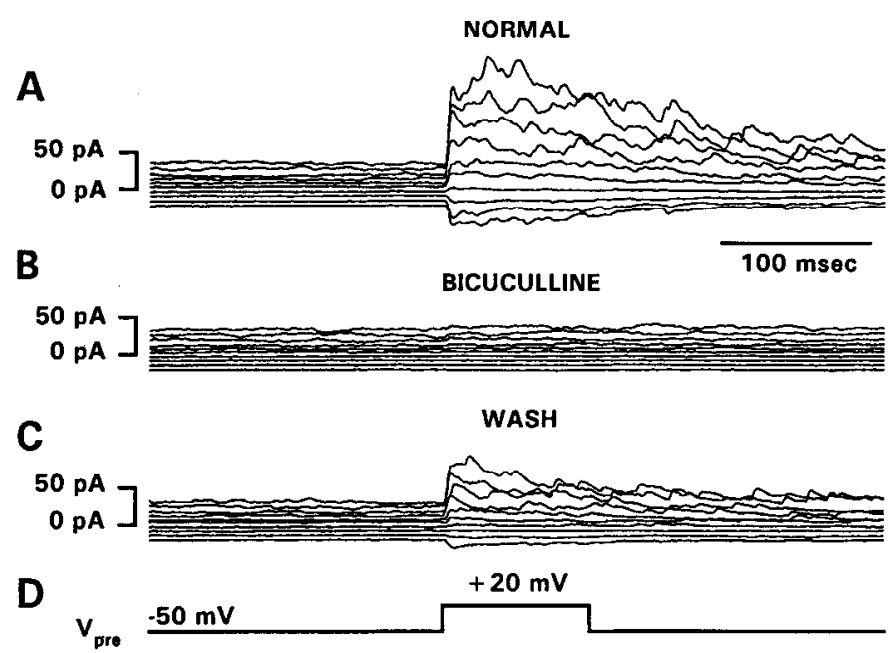

Figure 8. Synaptic transmission between pairs of amacrine cells is blocked by bicuculline. $A-C$, Postsynaptic current records were obtained with the same protocol as described for Figure 7 and with cells voltage clamped in the perforated-patch configuration with $\mathrm{Cs}$ in the pipette solutions. $A$, Postsynaptic currents were elicited in normal TEA-TTX external solution. $B$, The postsynaptic currents were abolished in an external solution containing $10 \mu \mathrm{M}$ bicuculline methiodide. $C$, Removal of bicuculline gave a partial recovery of the postsynaptic current. The same effect of bicuculline was found for all 20 cell pairs examined. sists of five consecutive $18 \mathrm{sec}$ segments of current record, the effects of $3 \mu \mathrm{M}$ GABA bath applied to a putative amacrine cell were enhanced during the pressure application of a solution containing $3 \mu \mathrm{M}$ diazepam in the presence of $3 \mu \mathrm{M}$ GABA. Of nine cells examined in this way, all showed an enhancement of GABA gated current with diazepam.

\section{Quantal events}

Discrete outward currents corresponding to a peak conductance change of about $300 \mathrm{pS}$ could often be seen in amacrine cells when no other cells were voltage clamped. Since all experiments were conducted in the presence of TTX, these spontaneous events could not be the consequence of presynaptic action potentials but must instead correspond to single quanta. Single "spontaneous" quanta were also seen at low frequency in postsynaptic

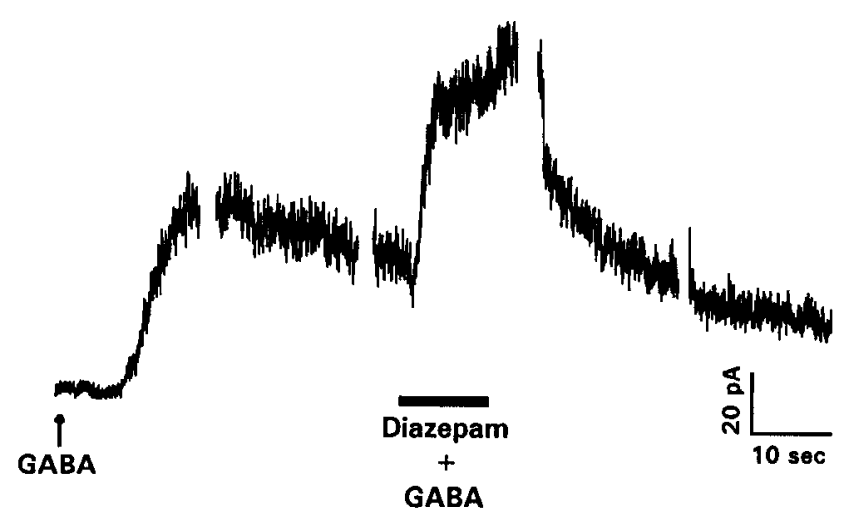

Figure 9. $\mathrm{GABA}_{\mathrm{A}}$ receptors on cultured amacrine cells have a benzodiazepine binding site. Current records from an isolated amacrine cell recorded in the whole-cell mode held at $0 \mathrm{mV}$ with $\mathrm{Cs}$ in the pipette solution. At the arrow, normal TEA-TTX external containing $3 \mu \mathrm{M}$ GABA was flushed into the dish and was present for the remainder of the experiment. During the time indicated by the bar, normal TEATTX with $3 \mu \mathrm{M}$ GABA plus $3 \mu \mathrm{M}$ diazepam was pressure ejected onto the cell and augmented the GABA current. The record consists of five separate $18 \mathrm{sec}$ data segments separated by short periods indicated by spaces in the trace. The delay in the action of GABA is due to dead space in the superfusion line and the dish. 
A

Figure 10. Quantal events can be resolved postsynaptically. $A-C$, Sets of discontinuous $2 \mathrm{sec}$ current records were obtained with both cells of a pair voltage clamped in the perforated-patch configuration using Cs pipette solutions. The "postsynaptic" cell was held at $0 \mathrm{mV}$, and the "presynaptic" cell was held at $-50 \mathrm{mV}$. $A$, In normal TEATTX external solution discrete quantal events can be detected. $B$, In the presence of $10 \mu \mathrm{M}$ bicuculline methiodide the quantal events were abolished. $C$, Quantal events return after the washout of the bicuculline.
B

BICUCULLINE

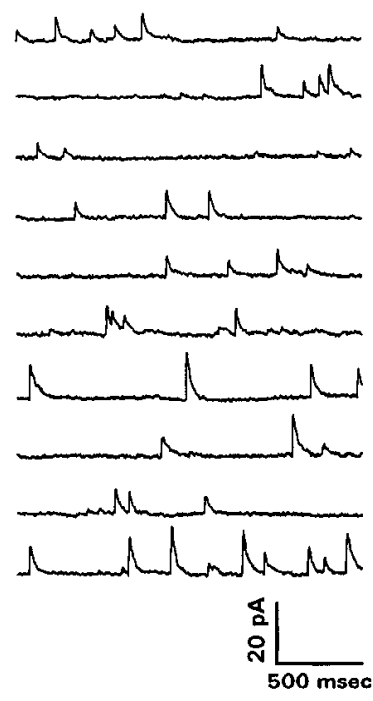

C

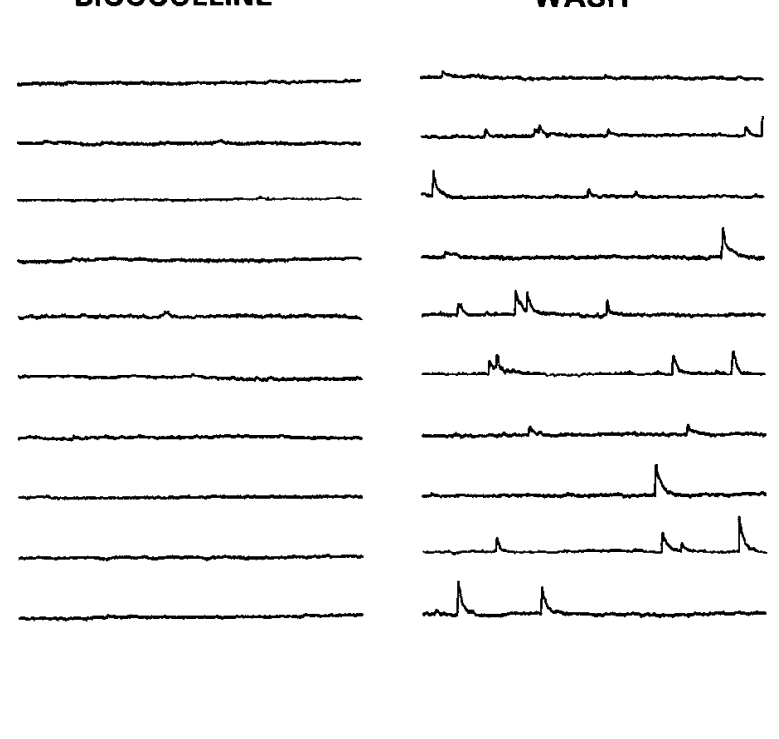

cells when a presynaptic amacrine cell was held at -50 or -60 mV. The "spontaneous" events seen under these conditions were similar in amplitude and form to those elicited by presynaptic steps to $-40 \mathrm{mV}$ and above (Fig. 6A), at least insofar as it is possible to resolve evoked responses into discrete events. Further evidence that spontaneous quanta are the same as those comprising the evoked postsynaptic current comes from experiments such as that of Figure 10 . In this figure, 10 discontinuous 2 sec current records are shown for a presynaptic holding potential of $-50 \mathrm{mV}$ and a postsynaptic holding potential of 0 $\mathrm{mV}$. The addition of $10 \mu \mathrm{M}$ bicuculline to the bath (Fig. 10B) abolished the discrete current events and the effect of bicuculline was reversible (Fig. 10C). Like evoked postsynaptic responses, discrete events were outward currents positive to about -50 $\mathrm{mV}$ but reversed sign at potentials negative to this. It appears then that the spontaneous postsynaptic events also arise from the activation of $\mathrm{GABA}_{\mathrm{A}}$ receptors.

The form and amplitude of quantal events werc cxamined in 11 cells selected for their low noise, though complete analyses were not performed on all cells. Long records containing up to 500 events were taken for subsequent analysis as illustrated by a representative cell shown in Figures 11-13. Only those events that were clearly isolated single quanta were selected for analysis of their waveform. The cell illustrated in Figure 11 showed spontaneous events that rose from $10 \%$ to $90 \%$ of their peak value in a mean time $( \pm \mathrm{SD})$ of $1.88( \pm 0.99) \mathrm{msec}$. This cell showed the fastest events of eight cells in which rise time was closely examined. The mean for all cells was $2.63( \pm 0.44) \mathrm{msec}$. A single exponential provided an adequate fit to the falling phase of spontaneous quanta (Fig. $11 B$ ). The mean value for the cell illustrated was $15.9( \pm 3.22)$ msec compared to the mean for seven cells of $19.3( \pm 3.8) \mathrm{msec}$.

In eight cells where event rates were low enough for every event to be resolved but in which a sufficient number of events was recorded, peak amplitude histograms were constructed as illustrated in Figure $11 \mathrm{~A}$. In the cell illustrated, the mean peak amplitude was $256 \mathrm{pS}$. Presuming that the $\mathrm{GABA}_{\mathrm{A}}$ channels underlying these quanta have a unitary conductance of $17 \mathrm{pS}$ as found elsewhere (Bormann et al., 1987), then the mean number of channels open simultaneously in the quantum is about 15 (mean of 8 cells $=17.5$ channels opened). The distribution of amplitudes, like those described for quanta in hippocampal cells (Bekkers et al., 1990; Edwards et al., 1990; Ropert et al., 1990) was in all cells positively skewed (Fig. 11A) through an excess of large events that makes up the extended right-hand side of the distribution. In the distribution shown in Figure $11 \mathrm{~A}$ one very large event (indicated with an arrow) would correspond to the opening of 116 channels, 7.7 times the mean value. It might be thought that the excess of large events was due to the simultaneous occurrence of single quanta but a calculation of the probability of this rules out such an explanation. In the cell from which this figure was drawn, the time intervals between events were well described by a Poisson distribution, supporting the idea that events occur randomly. Given this, we calculate that the probability of generating a single 116 channel event in Figure $11 \mathrm{~A}$ by the coincidence of eight mean amplitude events is $10^{-14}$. Another explanation for these large events is clearly required.

By aligning 12 clearly isolated quanta at their peaks, it was possible to derive an averaged quantum waveform as illustrated in Figure $11 \mathrm{C}$. To offset the bias introduced by choosing generally larger than average events, the average waveform was scaled to the mean peak amplitude before numerical integration was used to yield a mean quantal charge of $5.1 \mathrm{fC}$ per $\mathrm{mV}$ of driving force. This corresponds to a net flux of $32 \times 10^{3} \mathrm{Cl}^{-}$ ions per millivolt, per quantum.

\section{Electroanatomy of amacrine cells}

The cable properties of postsynaptic cells could distort the histogram of quantal amplitudes by reducing the recorded amplitude of distant events. To examine this possibility, we used whole-cell patch clamping to examine voltage trajectories for small injections of current in current-clamp mode ( $n=19$ cells). Figure $12 A$ shows a typical voltage decay that on a log voltage 

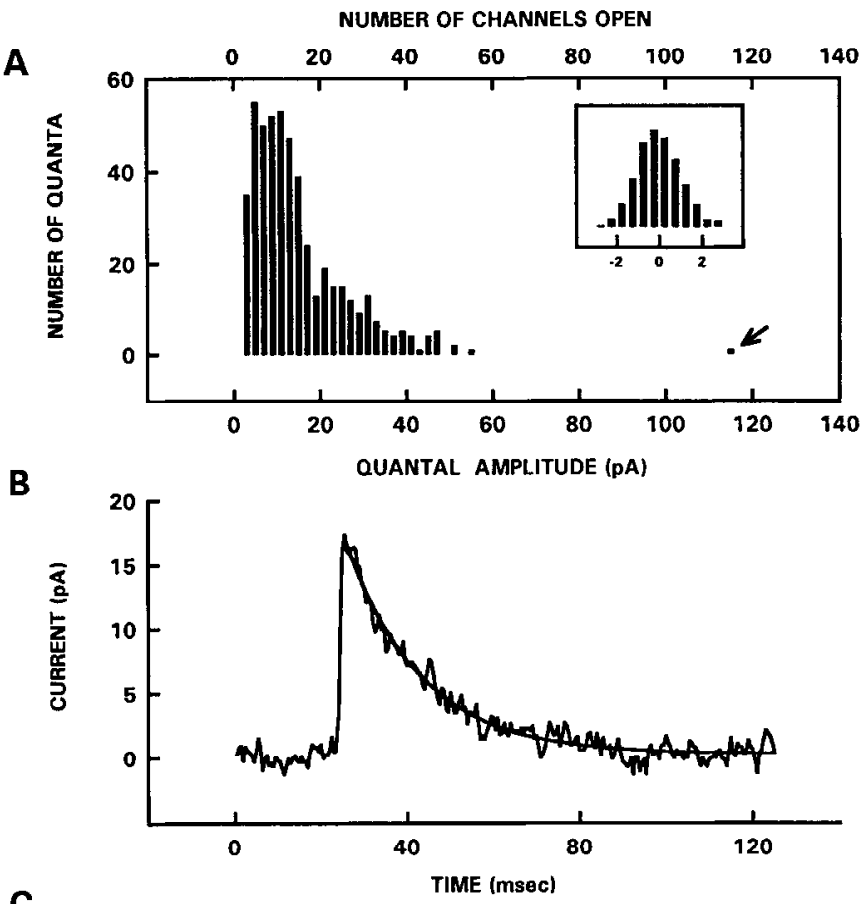

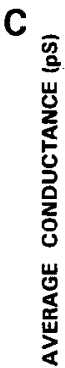

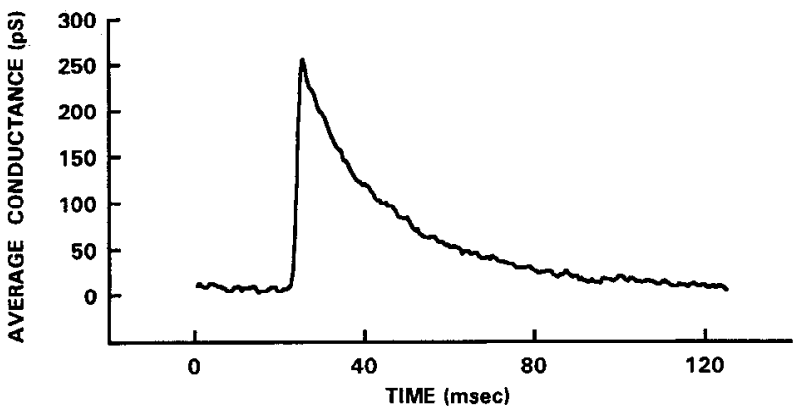

Figure 11. Amplitude distribution of 490 quantal events from an amacrine cell recorded in the whole-cell configuration in normal TEA-TTX external solution with $C$ s pipette solution and at a holding potential of $0 \mathrm{mV}(A)$. The mean quantal amplitude was $15.06 \mathrm{pA}( \pm 11.34 \mathrm{pA}$ $\mathrm{SD}$ ), with a mean conductance of $256 \mathrm{pS}$. On the same abscissa, the number of channels open was calculated from the conductance of GA$\mathrm{BA}_{\mathrm{A}}$ channels of $17 \mathrm{pS}$ (Bormann et al., 1987). The arrow indicates the occurrence of a single quantal event of amplitude $115.9 \mathrm{pA}$. The amplitude distribution of the baseline noise $( \pm 1.08 \mathrm{pA} \mathrm{SD})$ is illustrated in the inset and is taken from five $125 \mathrm{msec}$ sections of the recording that were apparently devoid of quantal events. In $B$, A single quantal event is illustrated, the falling phase being fit by an exponential function with a single decay time constant $\left(\tau_{D}\right)$ of $17.3 \mathrm{msec}$. $C$, An averaged waveform of quantal events was obtained by averaging 12 clearly isolated quanta aligned at their peaks, and then scaled to the mean peak conductance of $256 \mathrm{pS}$. The integral of the waveform yields a mean quantal charge of $5.1 \mathrm{fC}$ per millivolt of driving force.

axis is roughly linear over 2 orders of magnitude (Fig. 12B), indicating that the cell behaves as a single electrical compartment. A more detailed examination of this question was performed by taking the straightest region of the plot in Figure $12 B$ (between 11.6 and $50.0 \mathrm{msec}$ ) and fitting this to a best-fit straight line. The residuals for the whole curve were then displayed on linear axes with the expectation that separate electrical compartments would be revealed by further exponential components. As shown in Figure $12 C$, with the exception of a very fast component that is attributable to pipette capacitance, no extra exponentials may be seen. While the majority of cells
A

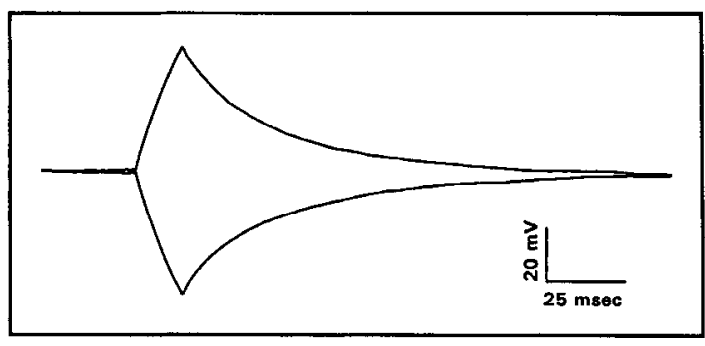

B

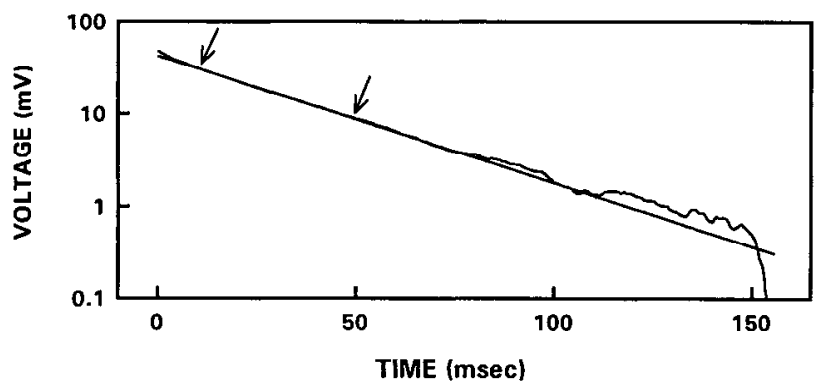

C

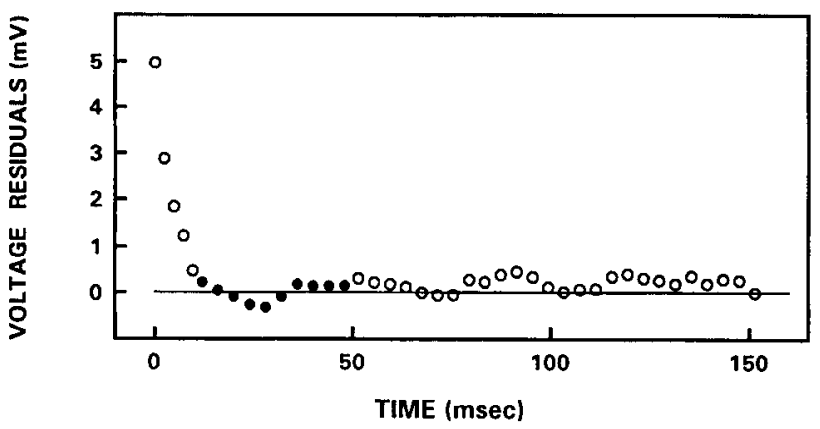

Figure 12. For the same cell illustrated in Figure 11 using the same solutions, voltage waveforms were generated by the injection of \pm 50 pA current steps in current-clamp mode $(A)$. The falling phases of the voltage were plotted on a log voltage axis, and in $B$, a typical voltage decay to a current step of $+50 \mathrm{pA}$ is shown. The voltage decay is roughly linear over 2 orders of magnitude. A best-fit straight line through the most linear section of this decay (between the arrows) is shown, and the voltage residuals for the whole curve are shown on linear axes $(C)$. Apart from a very fast component attributed to pipette capacitance, the residuals do not indicate that other exponentials, and hence other electrical compartments, are present.

conformed to this pattern, some cells with long, narrow dendrites were clearly not electrically compact by these criteria and recordings from these cells were not generally made and were not included for analysis.

A predicted consequence of cable filtering would be that quantal events of small amplitude should be slow relative to larger events. For eight cells, rise and fall times of quanta were plotted as a function of quantal amplitude. The Pearson product-moment correlation $(r)$ was used to determine if there was a relationship between amplitude and rise or decay times. As illustrated in Figure 13 a strong negative correlation between amplitude and rise times was never observed and for the data illustrated a dependency can be ruled out at the $1 \%$ confidence level $(r=0.125)$. Unexpectedly, a slight positive correlation between amplitude and decay time was seen in some cells. For the cell illustrated this was significant at the $1 \%$ level $(r=0.402)$, but we suspect that this correlation might be artifactual. A slight operator bias toward fitting shorter time constants to small- 


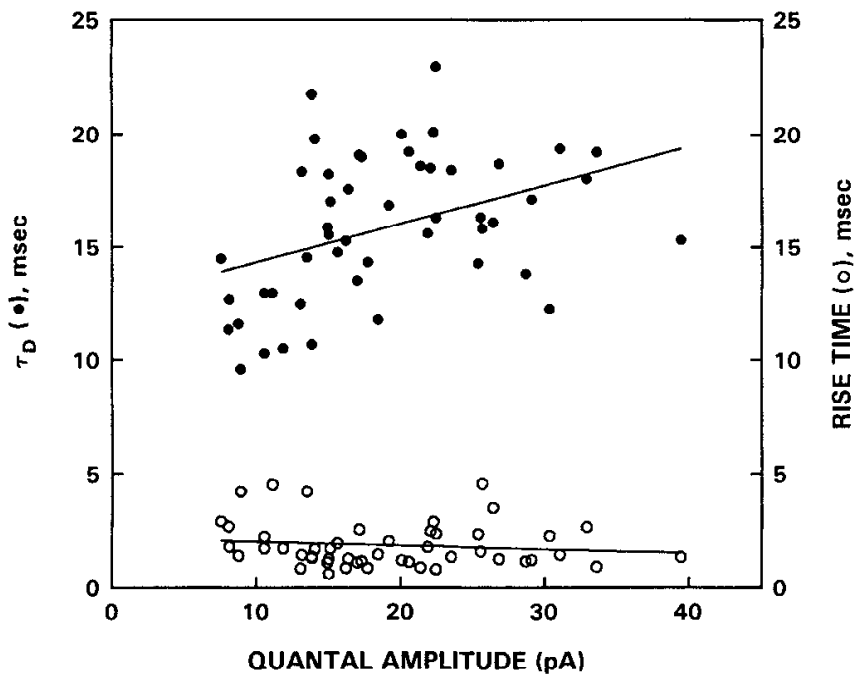

Figure 13. Rise times and decay time constants for the same cell as in Figure 11 for 49 quantal events are plotted against quantal sizc. Risc times were computed as growth time between $10 \%$ and $90 \%$ of peak, interpolating between data points.

amplitude events where the decaying tail is more quickly obscured by noise could explain this dependency, but no systematic tests of this idea have been performed.

\section{Estimation of maximum release rates}

Data on spontaneous quanta and on the amplitudes of evoked currents (Figs. 6, 11) may be used to give an estimate of the maximum quantal release rate at a single release site. If it is supposed that for a large presynaptic voltage step (see the step to $0 \mathrm{mV}$ in Fig. $6 A$ ) one vesicle is simultaneously released at every available release site very shortly after the onset of the voltage step, then an estimate of the numbcr of rclease sites is given by the peak current divided by the mean peak current of a quantum. For 11 cells, this number varied between 3 and 17, having a mean of 9.3 release sites.

This estimate of the number of release sites may be considered a lower bound to the number actually present since in order for the estimate to equal the actual number of sites, all release sites would have to release on every trial. As illustrated in Figure $6 \mathrm{~A}$ for steps positive to $0 \mathrm{mV}$, stepping from the presynaptic pulse potential back to the holding voltage of $-70 \mathrm{mV}$ was not accompanied by a noticeable discontinuity in postsynaptic current; in fact, in this and the majority of cells examined, the postsynaptic current continues as a plateau before falling gradually to zero. This is surprising since the presynaptic calcium current must change rapidly immediately following the return to the holding voltage. It is difficult to escape the conclusion from this that cytoplasmic calcium concentrations are saturating the release mechanism and some time is required before they fall to subsaturating values. An estimate of the release rate during this period of maximal release may be derived by dividing the postsynaptic "plateau" current by the mean charge per quantum ( $5.1 \mathrm{fC}$ per millivolt of driving force). For 11 cells the upper bound estimate of the release rate per release site varied between 13 and 43 with a mean for all cells of 25 quanta per site per second. These are surprisingly low values, especially when it is remembered that these are maximum values elicited by unnaturally large presynaptic voltage steps.

\section{Discussion}

Electrical coupling and reciprocal chemical synapses, as we report here for cultured amacrine cells, are characteristics of amacrine cells in the intact retina. Electrical coupling between amacrine cells of the mature retina from several species has been inferred from microelectrode recordings (Naka and Christensen, 1981) and from dye coupling (Jensen and DeVoe, 1982; Teranishi et al., 1984; Vaney, 1991) and is consistent with the observation of gap junctions between amacrine cells (WongRiley, 1974). Extensive reciprocal synaptic connections between amacrine cells have been observed in many retinas (e.g., Dubin, 1970). These reports are consistent with the idea that connections observed between amacrine cells in culture are the appropriate ones for these cells.

\section{Comparison with other synapses}

Retinal amacrine cells, because they do not generally encode signals as trains of action potentials, might be expected to show differences in synaptic transmission relative to those cells that traffic in action potentials. While some possible differences are apparent, the similarities are strong.

Our finding that quanta constitute very small currents and are therefore inferred to result from the opening of a small number of channels is consistent with some other recent studies. We estimate that an average quantum entails the simultaneous opening of about $17 \mathrm{GABA}_{\mathrm{A}}$ channels of $17 \mathrm{pS}$ conductance (Bormann et al., 1987). GABA A $_{\mathrm{A}}$ channels of different conductance are known (e.g., Verdoorn et al., 1990), and the exact number of channels per quantum depends on the presently unknown properties of our amacrine cell channels; nevertheless, the number is certainly orders of magnitude less than the 2500 channels opened at the frog neuromuscular junction (Katz and Miledi, 1970), the 1500 channels per glycine quantum in the lamprey spinal cord (Gold and Martin, 1983), or the 1600 per glycine quantum at the goldfish Mauthner neuron (Korn and Faber, 1990). In contrast to these high values, Edwards et al. (1990) report GABA quanta in hippocampal granule cells opening fewer than 30 channels and for hippocampal CA1 pyramidal neurons $\mathrm{GABA}_{\mathrm{A}}$ quanta are thought to comprise 12-20 channels (Ropert et al., 1990).

Quantal rise times of $2.6 \mathrm{msec}$ and a mean fall time constant of $19 \mathrm{msec}$ are similar to those of CA1 pyramidal neurons $(2.75$ $4 \mathrm{msec}$ and 21-28 msec, respectively; Ropert et al., 1990). GABA $_{\mathbf{A}}$ quanta in granule cells rise more quickly $(<1 \mathrm{msec})$ and fall with two time constants, $2.0 \mathrm{msec}$ and $54.4 \mathrm{msec}$ (Edwards et al., 1990). Only rough comparisons of these kinetics are possible since they were determined at different holding voltages and the voltage dependence of quantal kinetics is not known for any of these cells.

A clear generalization from our data is that quantal release can continuc hundreds of milliseconds after termination of a presynaptic voltage step, very likely reflecting a continued elevation of cytoplasmic calcium. At first sight this result is very different from the situation at the squid giant synapse, for example, where local calcium concentrations are thought to rise and fall on microsecond time scales (Smith and Augustine, 1988). The difference, however, may be more apparent than real since presynaptic calcium channels in squid giant synapse are normally open only very briefly. However, when caged $\mathrm{Ca}^{2+}$ is released into the cytoplasm (Delaney and Zucker, 1990), $\mathrm{Ca}^{2+}$ clearance can be slow and quantal release can continue long 
after the release of $\mathrm{Ca}^{2+}$ has been halted. Whether calcium buffering and removal or the relative proximity of calcium channels and release sites is genuinely different in these two preparations will require closer examination.

Like the findings for GABA and glutamate quanta in the hippocampus, we find that the amplitude distribution of quantal size is not Gaussian but is skewed by an overrepresentation of large events. A presynaptic origin for this asymmetry, depending on variance in vesicle size, has been suggested (Bekkers et al., 1990). An alternative explanation assigns the variance to the number of postsynaptic channels, which, it is assumed, are all liganded during a quantal event. A key concept in this second explanation is that postsynaptic receptors are present in one or more multiples of a certain number corresponding to a standard array. Some evidence for the definite peaks in quantal amplitude that this idea requires has been found in hippocampus (Edwards et al., 1990) but is not evident in our data (e.g., Fig. 11A). Possibly, larger sample sizes would reveal these peaks more clearly.

\section{Functional significance}

Our finding that evoked release occurs positive to $-40 \mathrm{mV}$ implies that the amacrine cells to which our cultured cells correspond in the retina may only rarely release transmitter. A second unexpected conclusion is that quantal release rates at individual release sites are low.

The conclusion that low release rates obtain at amacrine synapses clearly requires examination in the intact retina to rule out the possibility that it is an artifact of cultured cells. Low release rates are nevertheless consistent with the anatomical picture of many amacrine synapses in which only a small cluster of vesicles is seen (e.g., Dubin, 1970; Raviola and Raviola, 1982). Although electrophysiological data on amacrine cells in the chick retina are lacking, some indirect evidence from other retinas suggests that low release probability at synapses in the inner retina might be a general phenomenon. Freed ct al. (1992), in a recent study modeling transmission to ganglion cells, also conclude, based on the maximum measured conductance change, that the probability of synaptic release from rod bipolar cell synapses is low. Support for low release rates from bipolar cells comes also from high-resolution, whole-cell recordings from amphibian ganglion cells in isolated retinas or in retinal slices (Mittman et al., 1990; Mobbs et al., 1992). In particular, Mobbs et al. (1992) show that even for maximal light-evoked currents in ganglion cells, quantal noise, presumably of synaptic origin, can be large compared to the mean signal.

\section{References}

Akagawa K, Takada M, Hayashi H, Uyemura K (1990) Calcium-and voltage-dependent potassium channel in the rat retinal amacrine cells identified in vitro using a cell type-specific monoclonal antibody. Brain Res 518:1-5.

Altstein M, Dudai Y, Vogel Z (1981) Benzodiazepine receptors in chick retina: development and cellular localization. Brain Res 206: 198-202.

Barnes S, Werblin FS (1986) Gated currents generate single spike activity in amacrine cells of the tiger salamander retina. Proc Natl Acad Sci USA 83:1509-1512.

Barnstable CJ, Hofstein R, Akagawa K (1985) A marker of early amacrine cell development in rat retina. Dev Brain Res 20:286-290.

Bekkers JM, Stevens CF (1990) Presynaptic mechanism for long-term potentiation in the hippocampus. Nature 346:724-729.

Bekkers JM, Richerson GB, Stevens CF (1990) Origin of variability in quantal size in cultured hippocampal neurons and hippocampal slices. Proc Natl Acad Sci USA 87:5359-5362.

Bloomfield SA (1992) Effects of tetrodotoxin on receptive fields of amacrine and ganglion cells in the rabbit retina. Invest Ophthalmol Vis Sci 33:1173.

Bormann J, Hamill OP, Sakmann B (1987) Mechanism of anion permeation through channels gated by glycine and $\gamma$-aminobutyric acid in mouse cultured spinal neurones. J Physiol (Lond) 385:243-286.

Bray D (1970) Surface movements during the growth of single explanted neurons in culture. Cell Tissue Res 245:563-577.

Brecha N (1983) Retinal neurotransmitters: histochemical and biochemical studies. In: Chemical neuroanatomy (Emson PC, ed), pp 85-129. New York: Raven.

Delaney KR, Zucker RS (1990) Calcium released by photolysis of DM-nitrophen stimulates transmitter release at squid giant synapse. J Physiol (Lond) 426:473-498.

Dietzel ID, Drapeau P, Nicholls JG (1986) Voltage dependence of 5-hydroxytryptamine release at a synapse between identified leech neurones in culture. J Physiol (Lond) 372:191-205.

Dubin MW (1970) The inner plexiform layer of the vertebrate retina: a quantitative and comparative electron microscope analysis. J Comp Neurol 140:479-506.

Edwards FA, Konnerth A, Sakmann B (1990) Quantal analysis of inhibitory synaptic transmission in the dentate gyrus of rat hippocampal slices: a patch-clamp study. J Physiol (Lond) 430:213-249.

Elias of S, Barnes S, Werblin F (1987) The interaction of ionic currents mediating single spike activity in retinal amacrine cells of the tiger salamander. J Neurosci 7:3512-3524.

Freed MA, Smith RG, Sterling P (1992) Computational model of the on-alpha ganglion cell receptive field based on bipolar cell circuitry. Proc Natl Acad Sci USA 89:236-240.

Gleason E, Wilson M (1989) Development of synapses between chick retinal neurons in dispersed culture. J Comp Neurol 287:213-224.

Gleason E, Mobbs P, Nuccitelli R, Wilson M (1992) Development of functional calcium channels in cultured avian photoreceptors. Vis Neurosci 8:315-327.

Gold MR, Martin AR (1983) Characteristics of inhibitory post-synaptic currents in brain-stem neurones of the lamprey.J Physiol (Lond) 342:85-98.

Guiloff GD, Jones J, Kolb H (1988) Organization of the inner plexiform layer of the turtle retina: an electron microscopic study. J Comp Neurol 272:280-292.

Hamill OP, Marty A, Neher E, Sakmann B, Sigworth FJ (1981) Improved patch clamp techniques for high-resolution current recordings from cells and cell-free patches. Pfluegers Arch 391:85-100.

Horn R, Marty A (1988) Muscarinic activation of ionic currents measured by a new whole-cell recording method. J Gen Physiol 92:145159.

Huba R, Hofmann H-D (1990) Identification of GABAergic amacrine cell-like neurons developing in chick retinal monolayer cultures. Neurosci Lett 117:37-42.

Huba R, Hofmann H-D (1991) Transmitter-gated currents of GABAergic amacrine-like cells in chick retinal cultures. Vis Neurosci 6:303-314.

Hughes WF, LaVelle A (1974) On the synaptogenic sequence in the chick retina. Anat Rec 179:297-302.

Jensen RJ, DeVoe RD (1982) Ganglion cells and (dye-coupled) amacrine cells in the turtle retina that have possible synaptic connection. Brain Res 240:146-150.

Karten HJ, Brecha N (1983) Localization of neuroactive substances in the vertebrate retina: evidence for lamination in the inner plexiform layer. Vision Res 23:1197-1205.

Katz. B, Miledi R (1970) Membrane noise produced by acetylcholine. Nature 226:962-963.

Korn H, Faber DS (1990) Transmission at a central inhibitory synapse. IV. Quantal structure of synaptic noise. J Neurophysiol 63:198-222.

Korn SJ, Marty A, Connor JA, Horn R (1991) Perforated patch recording. In: Methods in neurosciences, Vol 4, Electrophysiology and microinjection (Conn PM, ed), pp 364-373. New York: Academic.

Li HB, Watt CB, Lam DMK (1985a) The presence of neurotensin in enkephalinergic and glycinergic amacrine cells in the chicken retina. Invest Ophthalmol Vis Sci 26:278.

Li HB, Watt CB, Lam DMK (1985b) The co-existence of two neuroactive peptides in a subpopulation of retinal amacrine cells. Brain Res 345:176-180. 
MacLeish PR, Townes-Anderson E (1988) Growth and synapse formation among major classes of adult salamander retinal neurons in vitro. Neuron 1:751-760.

Malgaroli A, Tsien RW (1992) Glutamate-induced long-term potentiation of the frequency of miniature synaptic currents in cultured hippocampal neurons. Nature 357:134-139.

Masland RH (1988) Amacrine cells. Trends Neurosci 11:405-410.

Mittman S, Taylor WR, Copenhagen DR (1990) Concomitant activation of two types of glutamate receptor mediates excitation of salamander retinal ganglion cells. J Physiol (Lond) 428:175-197.

Mobbs P, Everett K, Cook A (1992) Signal shaping by voltage-gated currents in retinal ganglion cells. Brain Res 574:217-223.

Naka K-I, Christensen BN (1981) Direct clectrical connections bctween transient amacrine cells in the catfish retina. Science 214:462464.

O'Brien RJ, Fischbach GD (1986) Excitatory synaptic transmission between interneurons and motoneurons in chick spinal cord cell cultures. J Neurosci 6:3284-3289.

O'Malley DM, Sandell JH, Masland RH (1992) Co-release of acetylcholine and GABA by the starburst amacrine cells. J Neurosci 12 1394-1408.

Raviola E, Raviola G (1982) Structure of the synaptic membranes in the inner plexiform layer of the retina: a freeze-fracture study in monkeys and rabbits. J Comp Neurol 209:233-248.

Ropert N, Miles R, Korn H (1990) Characteristics of miniature inhibitory postsynaptic currents in CA1 pyramidal neurones of rat hippocampus. J Physiol (Lond) 428:707-722.

Schwartz EA (1982) Calcium-independent release of GABA from isolated horizontal cells of the toad retina. J Physiol (Lond) 323:211227.
Schwartz EA (1987) Depolarization without calcium can release $\gamma$-aminobutyric acid from a retinal neuron. Science 238:350-355.

Smith SJ, Augustine GJ (1988) Calcium ions, active zones and synaptic transmitter release. Trends Neurosci 11:458-464.

Study RE, Barker JL (1981) Diazepam and (-) pentobarbital: fluctuation analysis reveals different mechanisms for potentiation of gamma-aminobutyric acid and responses in cultured central neurones. Proc Natl Acad Sci USA 81:7961-7964.

Teranishi T, Negishi K, Kato S (1984) Dye coupling between amacrine cells in carp retina. Neurosci Lett 51:73-78.

Vaney DI (1991) Many diverse types of retinal neurons show tracer coupling when injected with biocytin or neurobiotin. Neurosci Lett 125:187-190.

Verdoorn TA, Draguhn A, Ymer S, Seeburg PH, Sakmann B (1990) Functional properties of recombinant rat $\mathrm{GABA}_{\mathrm{A}}$ receptors depend upon subunit composition. Neuron 4:919-928.

Wässle H, Boos R (1992) Voltage- and transmitter-gated currents of AII-amacrine cells in a slice preparation of the rat retina. Invest Ophthalmol Vis Sci 33:1172.

Watt CB, Li T, Lam DMK, Wu SM (1988) Quantitative studies of enkephalin's coexistence with $\gamma$-aminobutyric acid, glycine and neurotensin in amacrine cells of the chicken retina. Brain Res 444:366370.

Werblin FS, Dowling JE (1969) Organization of the retina of the mudpuppy. II. Intracellular recording. J Neurophysiol 32:339-355.

Wong-Riley MTT (1974) Synaptic organization of the inner plexiform layer in the retina of the tiger salamander. J Ncurocytol 3:1-33.

Yazulla S, Kleinschmidt J (1983) Carrier-mediated release of GABA from retinal horizontal cells by potassium and acidic amino acid agonists. Brain Res 263:63-75. 